\title{
EFFECT OF INTRA-ROW SPACING ON THE INCIDENCE AND SEVERITY OF VIRAL DISEASES OF SOYBEAN (Glycine $\max$ (L.) MERR.) IN MOKWA, NIGERIA
}

\section{Isaac Yisa, Saliu Akinlabi Tiamiyu and Dauda S.N.}

\author{
National Cereals Research Institute, Badeggi P.M.B 8, Bida, Niger State, Nigerian. \\ Corresponding email: isaacyisa3@gmai.com; Tell: 07061976755
}

Cite this article:

Isaac Y., Saliu A.T., Dauda S.N. (2022), Effect of IntraRow Spacing on the Incidence and Severity of Viral Diseases of Soybean (Glycine max (L.) Merr.) in Mokwa, Nigeria. African Journal of Agriculture and Food Science 5(1), 11-16. DOI: $10.52589 / A J A F S-$ UPF9CV87

\section{Manuscript History}

Received: 31 Dec 2021

Accepted: 25 Jan 2022

Published: 9 Feb 2022

Copyright $\odot 2022$ The Author(s). This is an Open Access article distributed under the terms of Creative Commons AttributionNonCommercial-NoDerivatives 4.0 International (CC BY-NC-ND 4.0), which permits anyone to share, use, reproduce and redistribute in any medium, provided the original author and source are credited.
ABSTRACT: The study was conducted to assess the effect of intra-row spacing on the incidence and severity of viral disease on soybean during the wet cropping season in 2019 at the National Cereal Research Institute (NCRI), Mokwa field, located in the Southern Guinea savanna of Nigeria at an altitude of about 212 metres above sea level. Observation and data collection were done on the disease incidence and severity rating; also, plant height, the number of leaves, the number of pods per plant, the number of seeds per pod and Grain yield (t/ha) were determined at harvest. Data collected on growth and yield parameters were subjected to analysis of variance (ANOVA) using the general linear model (PROC GLM) procedure of SAS (2008). The means of significant $(p \leq 0.05) F$-test were separated using the Least Significant Difference (LSD) at a $5 \%$ probability level. The Elisa results obtained revealed the presence of Cowpea mottle virus, Cowpea yellow mosaic virus and Soybean mosaic virus. Also, the field trial showed that the different spacing and soybean cultivars investigated differ significantly on the variables tested. However, optimum spacing at $20 \mathrm{~cm}$ and $1448-2 E$ had significantly $(P<0.05)$ increased in all vegetative, reproductive growth and yield as well as reduced incidence of the soybean viruses detected in the field. From the above results, spacing at $20 \mathrm{~cm}$ with the cultivation of soybean cultivar $1448-2 E$ and appropriate cultural practices are hereby recommended to farmers in the area.

KEYWORDS: Intra-row spacing, Disease incidence, Disease Severity and Virus Disease on Soya beans. 


\section{INTRODUCTION}

Soybean (Glycine max (L.) Merr.) is one of the most important oil seed crops in the world, but its production has suffered from many problems of pests and diseases, including those caused by the viral pathogens. Soybean is susceptible to infection by several viruses, which substantially reduce the yield and quality of the produce (Balogun, 2008). For example, viral diseases are estimated to have reduced African soybean yields by over 760,000 metric tons in 2002 (Alegbejo, 2015). More than 111 viruses or strains, belonging to different virus genera and families, can infect soybean naturally or under experimental conditions (Salaudeen et al., 2016). Among these viruses, soybean is a natural host for 33 potentially important viruses.

As soybean cultivation increases in Nigeria [88,000 ha in 2010], the occurrence of virus and virus-like diseases can limit its production. Investigations of the incidence and distribution of soybean viruses are very important in developing diagnostic systems and appropriate control measures. Also, knowledge about which viruses are likely to be most prevalent in a particular region allows farm advisors to guide growers in disease management. There have been a few previous studies on soybean viral diseases and their distribution in Nigeria. In the southern guinea savanna, Tobacco ringspot virus (TRSV), Tobacco streak virus (TSV), and Tomato ringspot virus (ToRSV) were isolated from soybean plants showing pod set failure syndrome (PSF), which is of great concern to farmers in some seasons (Alegbejo, 2015). Adama et al. (2016) found that mechanical inoculation of the affected plants on soybean caused the same symptoms. Soybean mosaic virus (SMV) has also been reported previously from Nigeria (Arogundade et al., 2011).

The crop is grown under a range of environments, which probably affects its performance. The environmental factors that influence soybean productivity include climatic factors such as temperature, rainfall and day length, soil types and management practices such as plant densities, time of sowing, irrigation, herbicides and fungicides, some of which may do so partially to the effect of virus diseases. In particular, population density plays a cardinal role in determining seed yield. Above or below the threshold level of plant population would lead to intraspecies competition among plants for scarce resources which cause subnormal soybean seed yield. Adoption of suitable and optimum spacing would fulfill the objective of maximizing the yield of soybean. Hence, identification of the optimum population for each variety being tested becomes vital.

\section{Soybean Production}

Soybean (Glycine max [L.] Merr.) is a leguminous crop of global importance. In Nigeria, the land area under soybean cultivation has been on the increase in the last 20 years. This development is attributable to an increase in demand for human nutrition and animal feed. In 2013, Nigeria produced 600,000 tonnes of soybean estimated from 600,000 ha of land (FAO, 2013). The increased production of soybean in recent years has led to the dominance of soybean oil (about $20 \%$ ) among the various vegetable oils available for food use worldwide (FAO, 2013). 


\section{Production Constraints}

Several insect pests and foliar disease limit soybean production in Nigeria. Viruses that cause mosaic symptoms on the leaves affect soybean growing belts in the tropics. The production has suffered from many problems of pests and diseases, including those caused by viral agents. Soybean is susceptible to infection by several viruses, which substantially reduce yield and quality (Arogundade et al., 2014). For example, virus diseases are estimated to have reduced U.S. soybean yields by over 760,000 metric tons in 2002. More than 111 viruses or strains, belonging to different virus genera and families, can infect soybean naturally or under experimental conditions. Among these viruses, soybean is a natural host for 33 potentially important viruses (Balogun, 2008).

\section{Soybean Viruses}

Common viruses found in soybean fields are Soybean Mosaic Virus (SMV), Bean Pod Mottle Virus (BPMV), Alfalfa Mosaic Virus (AMV), and Tobacco Streak Virus (TSV). Other viruses, such as Tobacco Ringspot Virus (TRSV) and Bean Yellow Mosaic Virus (BYMV), are found, but at very low incidence in Nigeria (Alegbejo, 2015). The most damaging of these viruses are SMV and BPMV, with AMV appearing to be increasing in levels.

\section{Sources of Inoculum}

Seed transmitted inoculum is one common method of virus introduction. The virus infects the seed embryo, and once the seed is planted and germinates, the soybean remains infected throughout the season (Balogun, 2008). Virus-infected seed lots can exhibit lower levels of seed germination as well. Seed transmission is important in SMV and TSV dissemination, whereas AMV is generally 1 to 5\% seed transmitted, and BPMV seed transmission is less than $1 \%$. Seed mottling, also known as bleeding hilum, is a condition often associated with virus presence. While seed mottling can indicate a virus-infected seed lot, it is not a definitive diagnostic tool. Seed mottling is indicative of stress on the plant during the growing season, such as virus, drought, or temperature extremes in Nigeria (Alegbejo, 2015). Additionally, soybean viruses may or may not be associated with seed mottling, and soybean varieties differ in both susceptibility and propensity to mottle. Both SMV and BPMV infections will result in mottled seed, while AMV infections may or may not mottle and TSV infections generally do not produce discolored seed.

Insect vectors are another source of virus inoculum and are capable of spreading the virus from plant to plant and field to field. The soybean aphid is a vector for both SMV and AMV. Aphids feeding on infected plants (seed infected or infected non-soybeans) can then transmit the virus to healthy plants.

\section{Impact of Soybean Viruses on Yield and Seed Quality}

Soybean viruses have become more problematic in recent years due to the increased prevalence of insect vectors. The appearance of the soybean aphid (Aphis glycines) in 2000 and the increasing levels of bean leaf beetle (Cerotoma trifurcata) have played important roles in increasing the range and severity of specific soybean viruses. Yield can be reduced and seed quality can be diminished due to mottling and decreased vigor (Khan \& Jaiswal, 2011). 
Time of infection plays a role in yield loss severity (Balogun, 2008), with the earliest infections generally causing the greatest damage. Varieties differ in reaction to soybean viruses and some are able to yield well in the presence of high virus pressure, while others suffer significant yield loss. Insecticide seed treatment resulted in 2 area advantages but decreased virus incidence from $23 \%$ in non-treated to $10 \%$ in treated plots overall.

Viruses are most commonly associated with mottling, although it is not indicative of virus infection. Low seed weight, decreased germination and increased fungal infections often occur in virus-infected seed lots. Some varieties respond well to seed treatment and both a yield increase and reduction in seed mottling are observed. However, not all varieties react similarly (Aliyu et al., 2012). No consistent effect of Gaucho treatment for seed mottling was observed at Janesville. Producers can suffer financial penalties due to seed mottling, especially in foodgrade soybean production where entire crops would be rejected due to seed discoloration.

\section{Management of Soybean Viruses}

Control of seed transmitted viruses should be initiated in seed fields. Without testing, it is not possible to determine if a seed lot is infected or not. Seed companies need to ensure seed fields are clean and the resultant product is virus-free (Alegbejo, 2015). On a production level, control of vectors decreases virus incidence. By adjusting the planting date, vector impact can be lessened, and subsequent insecticide treatments can be minimized. Delaying planting can decrease BPMV incidence, simply by avoiding over-wintered beetles. If the delay is too long though, soybean aphids can become a problem, and the incidence of SMV and AMV will increase.

Control of virus vectors is also an effective approach. For BPMV, early spraying of insecticide to combat the overwintered beetles, and a late spraying to minimize pod damage by secondgeneration beetles, will decrease the level of BPMV. Insecticide seed treatments control earlyseason feeding and viruses but do not have a long enough residual to provide season-long control. Control of SMV is best achieved with early planting, but insecticides have reduced the incidence of SMV in late-planted soybeans (Arogundade et al., 2012).

\section{Row Spacing in Soybean Production}

Average row spacing for soybean production in some tropical regions is $75 \mathrm{~cm}$ with the majority of acres planted using row spacings of $19 \mathrm{~cm}(14 \%), 38 \mathrm{CM}(31 \%)$, and up to $76 \mathrm{~cm}$ $(40 \%)$ row spacing. Despite positive yield reports in soybean and lack of yield responses to narrow rows in corn (Zea mays L.) (Farnham, 2011), potential for greater incidence and severity of Sclerotinia stem rot (Sclerotinia sclerotiorum) in narrow rows (Grau \& Radke, 2014) has limited widespread adoption. However, another research indicates that cultivar selection and plant populations (Lee et al., 2005) are more important factors for Sclerotinia stem rot development. Lee et al. (2005) indicated row spacing $<76 \mathrm{~cm}$ produced a positive yield response in northern environments but a less consistent response south of $43^{\circ} \mathrm{N}$ latitude. Based on this, producers in Iowa, whose northern border is located at $43^{\circ} \mathrm{N}$ may not benefit from narrow-row soybean production as much as producers further north. Split-row planting equipment, planters that have additional row units between traditional $76 \mathrm{~cm}$ spaced row units that can be raised or lowered depending on the crop, may allow for the production of corn and soybean at the optimal row spacings for each crop. Increased equipment costs and the potential for no yield increases may prevent producers from investing in this planting technology. 
An advantage of narrow row spacing is more equidistant plant spacing that leads to increased canopy leaf area development and greater light interception earlier in the season. These changes in canopy formation increase crop growth rate, dry matter accumulation, and seed yield (Andrade et al., 2012).

\section{Specific Objectives}

- Investigate viral disease presence in the experimental plots in Mokwa.

- Assess disease incidence and severity of these viruses on soybean plants concerning intra row spacing.

- To determine seed yield response of the two varieties to changes in intra-row spacing.

\section{MATERIALS AND METHOD}

The field experiment was conducted during the wet cropping season in 2019 at the National Cereal Research Institute (NCRI), Mokwa field located in the Southern Guinea savanna of Nigeria at an altitude of about 212 metres above sea level. The site was previously cropped to maize. The climate is typical Southern guinea; rainfall is concentrated between August and September. Based on meteorological statistics, the total rainfall for the experimental period of June through August was $92.8 \mathrm{~mm}$, the mean air temperature was $26.8^{\circ} \mathrm{C}$, and mean relative humidity was $57.6 \%$.

\section{Treatments and Experimental Design}

Soybean cultivars TGX 1904-6F and TGX 1448-2E were used as plant material. The field experiment was set up in a factorial combination with three replications and intra-rows spacing, $5 \mathrm{~cm}, 10 \mathrm{~cm}, 15 \mathrm{~cm}$ and $20 \mathrm{~cm}$. The plot size was $3 \mathrm{x} 4 \mathrm{~m}$ to give $12 \mathrm{~m}^{2}$ plot sizes, $1.5 \mathrm{~m}$ pathway between plots respectively.

\section{Cultural Practices}

\section{Fertilization}

$60 \mathrm{~kg} \mathrm{ha}^{-1} \mathrm{P}_{2} \mathrm{O}_{5}$ and $60 \mathrm{~kg} \mathrm{ha}^{-1}$ nitrogen and $60 \mathrm{~kg} \mathrm{ha}^{-1}$ potassium were applied to each plot.

\section{Other practices}

Routine management practices were followed as when due.

\section{Data Collection}

Observation and data collection was done on the following:

- Disease incidence at reproductive stage

- Disease severity score at 6 WAP 
Other soybean growth and yield parameters include:

- $\quad$ Plant height at 3,6 and 9 weeks after planting (WAP)

- $\quad$ Numbers of leaves at 3,6 and 9 WAP

- $\quad$ Branch number per plant

- $\quad$ Days to $50 \%$ flowering

- $\quad$ Numbers of pods per plant

- $\quad 100$ seed weight $(\mathrm{g})$

- $\quad$ Seed weight yield $(\mathrm{kg} / \mathrm{ha})$

- $\quad$ Grain yield $(\mathrm{kg} / \mathrm{ha})$

\section{Analytical Tool}

Percentage incidence and disease symptoms severity score rates were employed to assess data obtained from the field.

Percent disease incidence $=\underline{\text { Plants with symptoms }} \times 100$

\section{Entire plant}

Disease severity is the percentage of leaves per plot with symptoms over the total number of leaves per plant on individual plants on five young leaves was assessed using a scale of 1-5 scoring scale based on phenotypic expression of the symptoms (Abdullahi et al., 2016).

Percentage Disease Severity $\quad=\quad$ Number of plant parts with symptom $\times 100$

Total Number of plant parts

\section{Statistical Analysis}

Other data collected on growth and yield parameters were subjected to analysis of variance (ANOVA) using the general linear model (PROC GLM) procedure of SAS (2008). The means of significant $(p \leq 0.05)$ F-test were separated using the Least Significant Difference (LSD) at a $5 \%$ probability level. 


\section{RESULTS AND DISCUSSION}

Detection of Viruses in Soybean Plots

Experiment: Surveyed soybean (12) (samples from the Northern part of Nigeria indexed for 8 antibodies

Antibodies Used: CAbMV, BlCMV, CMV, SBMV, CMeV, CYMV, CPMMV and SMV.

Method Used: Antigen Coated Plate (ACP)

Reading at OD*405 $\mathrm{nm}$ at $1 \mathrm{hr}$ and overnight reading

\section{ONE HOUR READING}

\begin{tabular}{|c|c|c|c|c|c|c|c|c|c|c|c|c|c|c|c|}
\hline & S.1 & S.2 & $\mathbf{S . 3}$ & S.4 & S.5 & S.6 & S.7 & S.8 & S.9 & S.10 & S.11 & S.12 & HEALTHY & DIEASED & BUFFER \\
\hline $\begin{array}{l}\text { Antibody } \\
\text { used } \\
\end{array}$ & & & & & & & & & & & & & & & \\
\hline CAbMV & 0.119 & 0.12 & 0.131 & 0.102 & 0.128 & 0.111 & 0.117 & 0.114 & 0.116 & 0.117 & 0.129 & 0.148 & 0.118 & 0.502 & 0.107 \\
\hline BlCMV & 0.127 & 0.126 & 0.166 & 0.134 & 0.12 & 0.111 & 0.126 & 0.124 & 0.141 & 0.116 & 0.174 & 0.147 & 0.133 & 0.481 & 0.098 \\
\hline CMV & 0.109 & 0.096 & 0.104 & 0.096 & 0.104 & 0.1 & 0.13 & 0.112 & 0.103 & 0.144 & 0.117 & 0.122 & 0.117 & 1.792 & 0.087 \\
\hline SBMV & 0.088 & 0.083 & 0.07 & 0.069 & 0.071 & 0.07 & 0.071 & 0.076 & 0.079 & 0.105 & 0.083 & 0.096 & 0.095 & 2.114 & 0.069 \\
\hline $\mathrm{CMeV}$ & 0.107 & 0.093 & 0.105 & 0.096 & 0.096 & 0.093 & 0.095 & 0.098 & 0.102 & 0.105 & 0.083 & 0.096 & 0.109 & 2.612 & 0.084 \\
\hline CYMV & 0.093 & 0.165 & 0.086 & 0.08 & 0.086 & 0.076 & 0.088 & 0.083 & 0.09 & 0.123 & 0.096 & 0.099 & 0.113 & 0.625 & 0.075 \\
\hline CPMMV & 0.166 & 0.125 & 0.119 & 0.132 & 0.134 & 0.118 & 0.115 & 0.124 & 0.122 & 0.096 & 0.198 & 0.19 & 0.133 & 0.505 & 0.09 \\
\hline SMV & 0.114 & 0.129 & 0.106 & 0.12 & 0.104 & 0.239 & 0.111 & 0.108 & 0.113 & 0.198 & 0.105 & 0.135 & 0.118 & 0.405 & 0.087 \\
\hline
\end{tabular}




\section{OVERNIGHT READING}

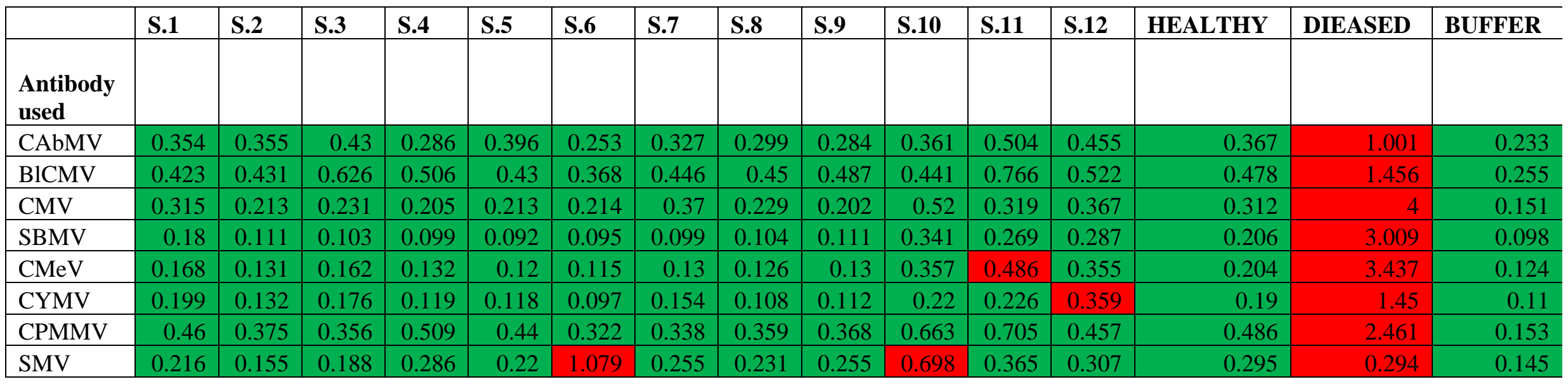

Note>-

Color Code

Positive
Negative

Positive is calculated based on Healthy value multiplied by 2 . 
Leaf samples with mean absorbance values at $405 \mathrm{~nm}$ (A405) twice or more than those of the healthy leaves in ELISA were considered virus-infected. Of the total leaf samples tested, Cowpea mottle virus (CMeV), Cowpea yellow mosaic virus (CYMV) and Soybean mosaic virus (SMV) were detected amongst the samples tested at the International Institute of Tropical Agriculture (IITA), Ibadan.

\section{Disease Incidence at 3, 6 and 9 WAP}

Table 4.1: Effect of intra-row spacing on incidence and severity of viral diseases of soybean in Mokwa, 2019

\begin{tabular}{lcccccc}
\hline & \multicolumn{3}{c}{ Disease incidence $(\%)$} & \multicolumn{3}{c}{ Disease severity } \\
\cline { 2 - 7 } Spacing (S) & 3 & 6 & 9 & 3 & 6 & 9 \\
\hline $5 \mathrm{~cm}$ & WAP & WAP & WAP & WAP & WAP & WAP \\
$10 \mathrm{~cm}$ & 27.6 & $42.5 \mathrm{a}$ & $86.7 \mathrm{a}$ & 10 & $48 \mathrm{a}$ & $2.7 \mathrm{a}$ \\
$15 \mathrm{~cm}$ & 26.7 & $40.4 \mathrm{a}$ & $85.8 \mathrm{a}$ & 10 & $50 \mathrm{a}$ & $2.6 \mathrm{a}$ \\
$20 \mathrm{~cm}$ & 25.7 & $35.4 \mathrm{~b}$ & $74.5 \mathrm{~b}$ & 10 & $30 \mathrm{~b}$ & $48 \mathrm{a}$ \\
LSD & 25.8 & $28.6 \mathrm{c}$ & $65.8 \mathrm{c}$ & 10 & $26 \mathrm{~b}$ & $28 \mathrm{~b}$ \\
Cultivars (C) & NS & 63.1 & 4.56 & NS & 13 & 17.4 \\
$1148-2 \mathrm{E}$ & & & & & & \\
$1904-6 \mathrm{~F}$ & 25.9 & 42.5 & 58.8 & 10 & 24 & 54 \\
LSD & 25.8 & 45.4 & 57.9 & 11 & 24 & 50 \\
Interaction (S x C) & NS & NS & NS & NS & NS & NS \\
\hline
\end{tabular}

Means followed by the same letter(s) in the same column are not significantly different at the $5 \%$ level of probability (DMRT)

LSD: Least significant difference

NS: Not significant

The two soybean cultivars were susceptible to the four viruses detected in the area. Soybean leaves were observed for symptom development at different stages of growth. Symptoms became visible on the leaves of the plants irrespective of the two cultivars and the spacing practiced at $3 \mathrm{WAP}$ (weeks after planting).

In the present investigation, four intra-rows spacing viz. $20 \mathrm{~cm} \times 75 \mathrm{~cm}(\mathrm{~S} 1), 15 \mathrm{~cm} \times 75 \mathrm{~cm}(\mathrm{~S} 2)$ and $10 \mathrm{~cm} \times 75 \mathrm{~cm}(\mathrm{~S} 3)$ and $5 \times 75 \mathrm{~cm}$ were tested. Disease incidence was observed among the spacing practiced and soybean cultivars throughout the trial. At 3 WAP, disease incidence was not significant $(p<0.05)$ in all the spacing tested. However, at 9 WAP, soybean spaced at 20 $\mathrm{cm}$ had the least viral disease incidence of $65.6 \%$, followed by plants spaced at $15 \mathrm{~cm}$ with $74.5 \%$ and those spaced at $10 \mathrm{~cm}$ and $5 \mathrm{~cm}$ had the highest diseases incidence of $85.8 \%$ and $86.7 \%$ respectively (Table 4.1 ). 
Similarly, disease incidence was not significant $(p<0.05)$ among the two soybean cultivars investigated at 3 WAP, soybean cultivar 1148 - 2E and $1904-6 \mathrm{~F}$ elicited disease incidence of $25.9 \%$ and $25.8 \%$ respectively. This trend continued to the completion of the trial (Table 4.1).

\section{Disease Severity at 3, 6 and 9 WAP}

Disease severity differed significantly $(p<0.05)$ amongst the different spacing investigated irrespective of the viral disease investigated only at 6 WAP. The progress of infection in the soybean plants is shown in Table 4.1. Disease severity increased progressively after 6 WAP; symptoms include mosaic, mottle and veinal chlorosis (Plate 4.1). Disease severity at 9 WAP was significantly $(p<0.05)$ higher in plants spaced at 5, 10 and $15 \mathrm{~cm}$ with $54 \%, 52 \%$ and $48 \%$ scores respectively, while spacing at $20 \mathrm{~cm}$ exhibited a symptom score of $28 \%$, which was mild.

At 3 and 6 WAP, disease severity was found not significant $(p<0.05)$ among the two soybean cultivars investigated; however, at 9 WAP, soybean cultivar $1148-2 \mathrm{E}$ and $1904-6 \mathrm{~F}$ had disease severity rates which ranged between 50\% and 54\% (Table 4.1).

\section{Plant Height at 3, 6 and 9 WAP}

The finding indicates that the widest spacing of $20 \mathrm{~cm} \times 75 \mathrm{~cm}$ (S3) responded significantly in case of plant height, number of leaves per plant and number of branches per plant (Table 4.2). At $9 \mathrm{WAP}$, soybean plants spaced at $20 \mathrm{CM}$ and $15 \mathrm{~cm}$ intra-rows produced significantly the tallest plants of $75.6 \mathrm{~cm}$ and $74.5 \mathrm{~cm}$ respectively whereas those spaced at $10 \mathrm{~cm}$ and $5 \mathrm{~cm}$ had the shortest plants of $85.8 \mathrm{~cm}$ and $63.4 \mathrm{~cm}$ respectively, which were similar as affected by viral diseases.

In respect to the response of the two soybean cultivars tested, they did not differ in height statistically; all the cultivars produced similar height throughout the period of study, irrespective of the viral infections.

\section{Number of Leaves at 6 and 9 WAP}

Table 4.2: Effect of intra-row spacing on plant height, number of leaves and branches on viral diseases of soybean in Mokwa, 2019

\begin{tabular}{lccccccc}
\hline & \multicolumn{3}{c}{ Plant height } & \multicolumn{2}{c}{ Number of leaves } & \multicolumn{2}{c}{ Number of branches } \\
\cline { 2 - 7 } Spacing (S) & 3 WAP & 6 WAP & 9 WAP & 6 WAP & 9 WAP & 6 WAP & 9 WAP \\
\hline $5 \mathrm{~cm}$ & 20.1 & $27.4 \mathrm{~b}$ & $63.4 \mathrm{~b}$ & $15 \mathrm{c}$ & $49 \mathrm{c}$ & $2 \mathrm{~b}$ & $3 \mathrm{c}$ \\
$10 \mathrm{~cm}$ & 20 & $27.9 \mathrm{~b}$ & $64.5 \mathrm{~b}$ & $18 \mathrm{~b}$ & $54 \mathrm{~b}$ & $2 \mathrm{~b}$ & $4 \mathrm{~b}$ \\
$15 \mathrm{~cm}$ & 20.2 & $31.0 \mathrm{a}$ & $74.5 \mathrm{a}$ & $18 \mathrm{~b}$ & $55 \mathrm{~b}$ & $4 \mathrm{a}$ & $6 \mathrm{a}$ \\
$20 \mathrm{~cm}$ & 20.3 & $316 \mathrm{a}$ & $75.6 \mathrm{a}$ & $21 \mathrm{a}$ & $66 \mathrm{a}$ & $5 \mathrm{a}$ & $7 \mathrm{a}$ \\
LSD & NS & 5.75 & 3.78 & 3.32 & 12.34 & 1.57 & 1.47
\end{tabular}




\begin{tabular}{lccccccc} 
Cultivars & & & & & & & \\
$1148-2 \mathrm{E}$ & 20.1 & 3.31 & 68.8 & $19 \mathrm{a}$ & $47 \mathrm{a}$ & 4 & $8 \mathrm{a}$ \\
$1904-6 \mathrm{~F}$ & 21.2 & 30.3 & 67.5 & $17 \mathrm{~b}$ & $42 \mathrm{~b}$ & 3 & $6 \mathrm{~b}$ \\
LSD & NS & NS & NS & 2.72 & 10.14 & NS & 1.21 \\
Interaction (S x C) & NS & NS & NS & NS & NS & NS & NS \\
\hline
\end{tabular}

Means followed by the same letter(s) in the same column are not significantly different at the $5 \%$ level of probability (DMRT)

LSD: Least significant difference

NS: Not significant

A significantly highest number of leaves (21 per plant) was observed from soybean plants spaced at $20 \mathrm{~cm}$ intra-rows at $6 \mathrm{WAP}$. Eighteen leaves per plant each were produced from those spaced at $15 \mathrm{CM}$ and $10 \mathrm{~cm}$ respectively while the spacing of $5 \mathrm{~cm}$ gave 15 leaves per plant. A similar trend was observed at $9 \mathrm{WAP}$. Soybean plants spaced at $20 \mathrm{~cm}$ produced significantly the highest leaf numbers of 66 per plant followed by those spaced at $15 \mathrm{~cm}$ and $10 \mathrm{~cm}$ with 55 and 54 leaves which were similar, while the least number of leaves per plant was found on plants spaced at $5 \mathrm{~cm}$ (Table 4.2).

Also, the two soybean cultivars tested did not differ in a number of leaves produced; however, at 9 WAP, soybean cultivar 1148 - 2E produced the highest number of leaves (47/plant) and 1904 - 6F gave 45 leaves per plant, which did not differ (Table 4.2).

\section{Number of Branches at 6 and 9 WAP}

At $6 \mathrm{WAP}$, plants spaced at $20 \mathrm{~cm}$ and $15 \mathrm{~cm}$ intra-rows exhibited significantly the highest number of branches which ranged between 4 and 5 , those spaced at $10 \mathrm{~cm}$ and $5 \mathrm{~cm}$ had 2 branches each. Also, at 9 WAP, plants spaced at $20 \mathrm{~cm}$ and $15 \mathrm{~cm}$ had 7 and 6 branches respectively and the significantly lowest number of branches per plant of 3 was found on plots with $5 \mathrm{~cm}$ intra-row spacing.

The number of branches was not significant $(p<0.05)$ among the two soybean cultivars investigated at $6 \mathrm{WAP}$, but at $9 \mathrm{WAP}$, soybean cultivar 1448 - 2E produced the significantly $(p<0.05)$ highest branch numbers $(8)$ as compared to $1904-6 \mathrm{~F}$, which gave 6 branches per plant (Table 4.2).

\section{Days to 50\% Flowering}

The significant difference was observed in 50\% days to flowering on the spacing investigated. Soybean plants spaced at $20 \mathrm{~cm}$ flowered early at 38 days after planting (DAP) followed by those spaced at $15 \mathrm{~cm}$ with 40 DAP while those on plots spaced at $10 \mathrm{~cm}$ and $5 \mathrm{~cm}$ flowered late at 44 DAP.

There was no significant difference $(p<0.05)$ among the two soybean cultivars investigated in respect to days to 50\% flowering; all cultivars flowered at the same time at 44 DAP (Table 4.3). 


\section{Number of Pods}

Plants spaced at $5 \mathrm{~cm}$ gave significantly the lowest number of pods per plant (31) and those spaced between $10 \mathrm{~cm}$ and $20 \mathrm{~cm}$ produced significantly the highest number of pods $(38,39$ and 40) respectively, which did not differ from one another.

Similarly, the 1148 - 2F cultivar produced the highest number of pods at harvest (41) while cultivar 1904 - 6F produced the least pods of 37 per stand (Table 4.3).

\section{Grain Yield of Soybean}

Table 4.3: Effect of intra-row spacing on viral diseases on days to 50\% flowering, number of pods, seeds, 100 seed weight and grain yield of soybean in Mokwa, 2019

\begin{tabular}{lccccc} 
Spacing (S) & $\begin{array}{c}50 \% \\
\text { flowering }\end{array}$ & $\begin{array}{c}\text { Number of } \\
\text { pods }\end{array}$ & $\begin{array}{c}\text { Number of } \\
\text { seeds }\end{array}$ & $\begin{array}{c}100 \text { seed } \\
\text { weight }(\mathrm{g})\end{array}$ & $\begin{array}{c}\text { Grain yield } \\
(\mathrm{t} / \mathrm{ha})\end{array}$ \\
\hline $5 \mathrm{~cm}$ & $44 \mathrm{a}$ & $31 \mathrm{~b}$ & 5 & 0.148 & $1.9 \mathrm{c}$ \\
$10 \mathrm{~cm}$ & $44 \mathrm{a}$ & $38 \mathrm{a}$ & 5 & 0.154 & $2.9 \mathrm{~b}$ \\
$15 \mathrm{~cm}$ & $40 \mathrm{~b}$ & $39 \mathrm{a}$ & 6 & 0.147 & $3.1 \mathrm{~b}$ \\
$20 \mathrm{~cm}$ & $38 \mathrm{~b}$ & $40 \mathrm{a}$ & 6 & 0.158 & $3.9 \mathrm{a}$ \\
LSD & 3.16 & 7.38 & $\mathrm{NS}$ & 0.02 & 0.84 \\
Cultivars & & & & & \\
\hline $1148-2 \mathrm{E}$ & 44 & $41 \mathrm{a}$ & 5 & 0.168 & $3.2 \mathrm{a}$ \\
$1904-6 \mathrm{~F}$ & 44 & $37 \mathrm{~b}$ & 5 & 0.163 & $2.9 \mathrm{~b}$ \\
LSD & $\mathrm{NS}$ & 6.06 & $\mathrm{NS}$ & $\mathrm{NS}$ & 0.69 \\
Interaction (S x C) & $\mathrm{NS}$ & $\mathrm{NS}$ & $\mathrm{NS}$ & $\mathrm{NS}$ & $\mathrm{NS}$ \\
\hline
\end{tabular}

Means followed by the same letter(s) in the same column are not significantly different at the $5 \%$ level of probability (DMRT)

LSD: Least significant difference

NS: Not significant

Significantly, the highest grain yield of $3.9 \mathrm{~kg} /$ plot was obtained from plants spaced $20 \times 75$ $\mathrm{cm}$; those of $15 \times 75 \mathrm{~cm}$ and $10 \times 75 \mathrm{~cm}$ plots gave 3.1 and $2.9 \mathrm{~kg} / \mathrm{plot}$ respectively whereas the least grain yield of $1.9 \mathrm{~kg} / \mathrm{plot}$ was gotten from plots spaced at $5 \mathrm{x} 75 \mathrm{~cm}$.

Soybean cultivar 1448 - 2E had a significantly highest grain yield of $3.2 \mathrm{~kg} /$ plot while cultivar 1904 - 6F gave the least of $2.9 \mathrm{~kg} / \mathrm{plot}$ (Table 4.3).

\section{DISCUSSION}

It is clear that with wider spacing or in other words, slower plant population per unit area, the individual plant got more area for plant nutrients, more light and air for better development of growth characters. Similarly, such spacing (wider) also protects crop plants from pest and disease incidence (Grau \& Radke, 2014). As the plant population increased, keen competition 
among plants for nutrients, light and air resulted in poor vegetative growth and a higher incidence of pests such as weeds and other pathogens. As seen in this trial, a higher incidence of viral infections was recorded from plots with high plant density $(5-10 \mathrm{~cm})$; this might be as a result of the closeness of the plants which might have encouraged mechanical transmission of the viruses from the infected crops to the healthy ones as well as insect vector transmission. As far as yield is concerned, the highest plant population per hectare or wide spacing of $20 \mathrm{x}$ $75 \mathrm{~cm}$ proved optimum. The most interesting point is to note that at wider spacing where the best growth attributes have been observed, the incidence of virus infections reduced due to a fewer number of plants.

Varieties differ in reaction to soybean viruses, and some are able to yield well in the presence of high virus pressure while others suffer significant yield loss (Aliyu, 2012). As observed in this study, a 1448 - 2E cultivar which had the significantly highest grain yield might be due to its tolerance or resistance level to the virus detected or its genetic make-up.

\section{CONCLUSION}

Results obtained revealed the presence of Cowpea mottle virus, Cowpea yellow mosaic virus and Soybean mosaic virus. Also, the field trial showed that the different spacing and soybean cultivars investigated differ significantly on the variables tested. However, optimum spacing at $20 \mathrm{~cm}$ and $1448-2 \mathrm{E}$ had significantly $(\mathrm{P}<0.05)$ increased all vegetative, reproductive growth and yield as well as reduced incidence of the soybean viruses detected in the field. From the above results, spacing at $20 \mathrm{~cm}$ with the cultivation of soybean cultivar $1448-2 \mathrm{E}$ and appropriate cultural practices are hereby recommended to farmers in the area to improve their productivity and good quality seed.

\section{REFERENCES}

Alegbejo, M. D (2015). Virus and virus-like diseases of crops in Nigeria. Zaria, Nigeria. Ahmadu Bello University Press. 273pp

Andrade, F.H., P. Calvino, A. Cirilo, and P. Barbieri. (2012). Yield responses to narrow rows depend on increased radiation interception. Agron. J. 94:975-980.

Arogundade, O., Balogun, O. S., Shokalu, O and Aliyu, T. H.(2011). Influence of Cowpea mottle virus and Cucumber mosaic virus on the growth and yield of six lines of soybean (Glycine max L.Merrril). Journal of Agricultural Science, 2, 72-78.

Balogun, O. S. (2008). Survey of the symptoms and viruses associated with cowpea (Vigna unguiculata (L).) in the Agro ecological zones of Kwara State, Nigeria. Ethiopian Journal of Environmental Studies and Management, 5(4), 613-619.

FAO (Food and Agriculture Organization) (2013). Soybean production statistics. Available at http://faostat.fao.org/site/567/DesktopDefault.aspx?PageID=567\#ancor. Accessed on May 1, 2017

Farnham, D.E. (2011). Row spacing, plant density, and hybrid effects on corn grain yield and moisture. Agron. J. 93:1049-1053.

Grau, C.R., and V.L. Radke. (2014). Effects of cultivars and cultural practices on Sclerotinia stem rot of soybean. Plant Dis. 68:56-58 
Khan, A.R. and Jaiswal, R.C. (2011).Effect of nitrogen, plant spacing and green fruit pickings in the seed production of okra (Abelmoschus esculentus Moench). Vegetable Sci., 15(1): $8-14$.

Lee, C.D., K.A. Renner, D. Penner, R. Hammerschmidt, and J.D. Kelly. (2005). Glyphosateresistant soybean management system effect on Sclerotinia stem rot. Weed Technol. 19:580-588

Salaudeen, M. T., Adama, C. J., Ogunsola, K. E., Ishaq, M. N., Abdullahi, A. A and Abdulkadir A (2016). Resistance of Soybean Lines Infected with Blackeye cowpea mosaic virus Under Controlled conditions. Int'l Journal of Agric. and Rural Dev. 19(2): 2720-2729. 